\title{
PULMONARY TUBERCULOSIS: HEMATOLOGY, SERUM BIOCHEMISTRY AND THE RELATION WITH THE DISEASE DURATION
}

\author{
OLIVA V. M. (1), CEZÁRIO G. A. G. (2), COCATO R. A. (2), MARCONDES- \\ MACHADO J. (2)
}

(1) Botucatu Medical School, São Paulo State University-UNESP, Botucatu, São Paulo State, Brazil; (2) Department of Tropical Diseases, Botucatu Medical School, UNESP, Botucatu, São Paulo State, Brazil.

\begin{abstract}
The aim of the present study was to analyze the relationship between hematological and biochemical parameters and tuberculosis process activity time according to clinical complaint duration. It was a retrospective study analyzing medical records from 80 pulmonary tuberculosis patients at Botucatu Medical School University Hospital (Botucatu, São Paulo State, Brazil), who were divided into 2 groups according to clinical complaint duration: Group 1 (G1) - up to three months; Group 2 (G2) - over three months. Parameters included: age, gender, bacilloscopy, erythrocyte sedimentation rate (ESR), platelet count, alpha1-globulin, alpha2globulin, gamma globulin, mucoprotein, alpha1-acid glycoprotein values, and the presence of risk factors such as smoking, alcoholism, drug addiction, sexual promiscuity, contact with tuberculosis carriers, and previous treatment. Groups were compared by calculating $t$ and $p$, and Chi-square $\left(\mathrm{X}^{2}\right)$ and $p$. Comparisons revealed a tendency towards smoking with a higher frequency of smokers in $\mathrm{G} 1(0.05<p<0.10)$. G1 also tended to present greater platelet values than $G 2 \quad(0.05<p<0.10)$ and presented significantly higher ESR values than G2 $(p<0.05)$. Other factors did not show any significantly different behavior between groups $(p>0.05)$. A correlation was found between ESR, platelet count, smoking and less than three months clinical duration.
\end{abstract}

KEY WORDS: Mycobacterium tuberculosis, pulmonary tuberculosis, smoking, hematolological and biochemical parameters, erythrocyte sedimentation rate.

CONFLICTS OF INTEREST: There is no conflict.

\section{CORRESPONDENCE TO:}

JUSSARA MARCONDES-MACHADO, Departamento de Doenças Tropicais, Faculdade de Medicina de Botucatu, UNESP, Distrito de Rubião Júnior, S/N, 18618000, Botucatu, SP, Brasil. Phone: +55 1438116212.

Email: jussaramarcondes@uol.com.br. 


\section{INTRODUCTION}

Tuberculosis (TB) is a highly prevalent chronic infectious disease caused by Mycobacterium tuberculosis, an aerobic intracellular binding bacterium (bacillus); because of this characteristic it prefers tissues which are always in contact with high oxygen levels, as in the lung. After inhaling the bacillus, transmitted by tiny droplets of saliva, the infected individual may develop the disease depending on his immunological state $(1,16)$. After taking up residence in the lung, M. tuberculosis can disseminate to any part of the organism (16).

Globally, M. tuberculosis infection remains at epidemic levels (18). One third of the world's population is infected and approximately 3 million people die annually from pulmonary tuberculosis, overtaking the number of deaths due to acquired immune deficiency syndrome (AIDS), malaria, diarrhea, leprosy, and other tropical diseases combined (26). In Brazil, there are about 100,000 new cases and 6,000 deaths reported every year (9). This makes tuberculosis the $4^{\text {th }}$ highest cause of death from infectious diseases, and even though treatment is performed on an outpatient basis, it is the $9^{\text {th }}$ highest cause of hospitalization from infectious diseases and the $7^{\text {th }}$ highest in cost from these hospitalizations (7).

Around $10 \%$ of tuberculosis cases are in the under $20 \mathrm{~s}$, with the most affected age group being the $20-49$-year-old, accounting for $70 \%$ of all those affected. It affects three times as many men as women (21).

Routine diagnosis of pulmonary and extra-pulmonary tuberculosis is by bacilloscopy (BAAR); it is an easy, quick and safe method to justify starting treatment. However, a more specific and sensitive method is mycobacteria isolation in culture medium, which has the disadvantage of slow bacteria growth resulting in longer diagnosis time (13).

Initially, combat against M. tuberculosis is mediated by inflammatory cytokines such as IL-1, IL-2, and mainly TNF- $\alpha$; these are essential for controlling acute infection by both local inflammatory process and macrophage (microbicide mechanisms) activation $(14,30)$. TNF- $\alpha$, produced by alveolar macrophages, increases nitric oxide (NO) expression and inducible nitric oxide synthase enzyme (iNOS), favoring granuloma maintenance and integrity (19). Excess TNF- $\alpha$ associated with IL-1 could be related to disease pathogenesis, as these cytokines cause fever, tissue necrosis, and cachexia (17). 
IL-2 and IFN- $\gamma$ secretion which characterizes Th1 profile is seen during initial infection stages and Th2 profile, characterized by IL-4, IL-5, IL-6, and IL-10 secretion, is apparent in later stages of the disease (12).

Bacillus survival inside macrophages causes the immune response of immunocompetent individuals to constantly activate $\mathrm{T}$ lymphocytes which will produce large quantities of INF- $\gamma$ and TNF- $\alpha$ leading to the accumulation of macrophages and lymphocytes, which possibly form the granuloma and latent foci. In immunosupression states, these foci may be reactivated and the infection progress $(8,11)$.

Cytokines are responsible for clinical and laboratory alterations which occur during the inflammatory process, such as fever, leukocytosis, thrombocytosis, and acutephase hepatic responses (2).

In tuberculosis, for example, the inflammatory process has increased concentrations of several serum proteins, called acute-phase proteins. These include $\alpha 1$ glycoprotein acid, mucoprotein, $\alpha 1$-globulin, $\alpha 2$-globulin, and the $\gamma$-globulins (4).

Mucoprotein is a glycoprotein rich in acid polysaccharides, the main component being a1-glycoprotein acid, the inflammatory activity marker responsible for performing immunomodulatory activities $(23,28)$. The globulins $(\alpha, \beta$ and $\gamma$ ) influence ESR, a non-specific test for inflammatory and infectious processes used to evaluate activity level and disease extent, response to treatment, and the prognosis of subacute and chronic diseases such as tuberculosis $(22,25,29)$.

A relevant hematological parameter in pulmonary tuberculosis is platelet count. When high, it characterizes an abnormal fibrinolytic system which leads to hypercoagulability $(6,15)$.

The objective of this work was to analyze the relationship of hematological and biochemical parameters with tuberculosis process activity according to clinical duration.

\section{PATIENTS AND METHODS}

This study analyzed 80 patients diagnosed with pulmonary tuberculosis and treated at the Infectious and Parasitic Diseases Service of the University Hospital, Botucatu Medical School, São Paulo State University - UNESP, Brazil, between January 1992 and December 2003. 
Patients were divided into two groups according to clinical disease duration: G1, up to three-month duration $\left(n_{1}=41\right)$; and $G 2$, over three-month duration $\left(n_{2}=39\right)$. The three-month-group split point is based on the mean time that patients seek medical attention in the above Service.

Patient data were obtained by analyzing medical records considering age, gender, bacilloscopy results, ESR, platelet count, and acute-phase serum protein counts; the latter being $\alpha-1$ globulin, $\alpha-2$ globulin, $\gamma$-globulin, mucoprotein and $\alpha-1$ glycoprotein acid. The following tuberculosis risk factors were also noted: smoking, alcoholism, drug abuse, sexual promiscuity, contact with tuberculosis, and previous antituberculosis treatment.

Data comparisons between the two groups were made using $t$ and $p$ statistics; and Chi squared $\left(x^{2}\right)$ and $p$ calculations. Values were considered significant when $p<0.05$; and there was a tendency towards significance when $0.05<p<0.10$.

This study was approved by the Human Research Ethics Committee of Botucatu Medical School, UNESP.

\section{RESULTS}

Gender distribution in both groups was similar with a predominance of males. G1 had $28(48.28 \%)$ and G2, $30(51.72 \%)$ men with pulmonary tuberculosis (Table 1). Mean age in both groups was similar ( $\mathrm{G} 1: 47$ years \& $\mathrm{G} 2: 45$ years).

Of the 80 patients in this series, 49 (61.25\%) presented positive sputum bacilloscopy without significant difference between groups (G1: 53.06\% positivity \& G2: 46.94\%; Table 2)

Of the pulmonary tuberculosis risk factors, Figure 1 shows smoking as the most frequently reported with a total of $59(73.75 \%)$ confirming they were smokers; 34 from G1 (57.63\%) and 25 (42.37\%) from G2. There was a tendency between groups towards more smokers with less than three months clinical duration (G1).

History of alcoholism was confirmed by 23 (48.94\%) patients in $\mathrm{G} 1$ and $24(51.06 \%)$ in $\mathrm{G} 2$ ( $p>0.05)$. Contact with other tuberculosis sufferers was reported by $20(25 \%)$ patients with equal distribution in both groups. Approximately a quarter of the patients reported prior tuberculosis treatment, 9 (42.86\%) from G1 and 12 (57.14\%) from G2. Only 11 patients reported the use of illicit drugs and sexual promiscuity; however, there was no significant difference between groups (Figure 1). 
For hematological parameters, mean platelet count in $\mathrm{G} 1$ was $429 \times 10^{3} / \mathrm{mm}^{3}(121-$ $\left.1023 \times 10^{3} / \mathrm{mm}^{3}\right)$, and $367 \times 10^{3} / \mathrm{mm}^{3}\left(118-605 \times 10^{3} / \mathrm{mm}^{3}\right)$ in G2. G1 showed a tendency to higher platelet counts than G2 with G1 being close to the upper normal limit $\left(450 \times 10^{3} / \mathrm{mm}^{3}\right)$. Erythrocyte sedimentation rate (ESR) (reference values for men: $3-5 \mathrm{~mm} / \mathrm{h}$; for women: $4-7 \mathrm{~mm} / \mathrm{h}$ ) was elevated in both groups, with a mean of $50 \mathrm{~mm} / \mathrm{h}(24-65 \mathrm{~mm} / \mathrm{h})$ in $\mathrm{G} 1$ and $43 \mathrm{~mm} / \mathrm{h}(2-56 \mathrm{~mm} / \mathrm{h})$ in $\mathrm{G} 2$ with significant difference between groups (G1>G2).

There were no significant differences between groups for serum proteins. However, means of a1-globulin (G1=0.43g\%; G2=0.42g\%), $\alpha 2$-globulin (G1=1.05g\%; $\mathrm{G} 2=0.95 \mathrm{~g} \%$ ), Y-globulin ( $\mathrm{G} 1=2.01 \mathrm{~g} \% ; \mathrm{G} 2=1.76 \mathrm{~g} \%)$, mucoprotein (G1=21.2mg\%; $\mathrm{G} 2=18.0 \mathrm{mg} \%$ ), and $\alpha 1$-glycoprotein acid (G1=236mg\%; G2=236mg\%) were above the upper normal limits in both groups (Table 3 ).

Table 1. Gender distribution of patients with pulmonary tuberculosis.

\begin{tabular}{ccccc}
\hline \multicolumn{5}{c}{ Gender } \\
\hline G1 & Male & $\%$ & Female & $\%$ \\
G2 & 28 & 48.28 & 13 & 59.00 \\
\hline TOTAL & 30 & 51.72 & 9 & 41.00 \\
\hline
\end{tabular}

G1: complaint duration up to 3 months.

G2: complaint duration over 3 months.

Statistics: $p>0.25$; Comment: $\mathrm{G} 1=\mathrm{G} 2$

Table 2. Bacilloscopy results.

\section{Bacilloscopy}

\begin{tabular}{ccccc}
\hline G1 & Positive & \% & Negative & $\%$ \\
G2 & 26 & 53.06 & 15 & 48.39 \\
\hline TOTAL & 23 & 46.94 & 16 & 51.69 \\
\hline
\end{tabular}

G1: complaint duration up to 3 months.

G2: complaint duration over 3 months.

Statistics: $p>0.50$; Comment: $\mathrm{G} 1=\mathrm{G} 2$ 
Table 3. Analysis of hematological and biochemical parameters of patients with pulmonary tuberculosis.

\begin{tabular}{|c|c|c|c|}
\hline \multicolumn{4}{|c|}{ Hematological and Biochemical Parameters } \\
\hline & \multicolumn{2}{|c|}{ Mean } & \multirow[t]{2}{*}{ Reference Values } \\
\hline & $\mathbf{G 1}$ & $\mathbf{G 2}$ & \\
\hline Platelet count $\left(X 10^{3} / \mathrm{mm}^{3}\right)$ & 429 & 367 & $150-450$ \\
\hline a1-globulin (g\%) & 0.43 & 0.42 & $0.10-0.40$ \\
\hline$\alpha 2-g l o b u l i n(g \%)$ & 1.05 & 0.95 & $0.40-0.90$ \\
\hline Y-globulin (g\%) & 2.01 & 1.76 & $0.70-1.70$ \\
\hline Mucoprotein (mg/dl) & 21.20 & 18.00 & $5.7-12.5$ \\
\hline a1-glycoprotein acid (mg\%) & 236.00 & 236.00 & $30-120$ \\
\hline $\operatorname{ESR}(\mathrm{mm} / \mathrm{h})$ & 50 & 43 & Men 3-5 Women 4-7 \\
\hline
\end{tabular}

G1: complaint duration up to 3 months.

G2: complaint duration over 3 months.

Platelet count: $0.05<p<0.10 ; \mathrm{G} 1 \geq \mathrm{G} 2$ (tendency)

a1-globulin: $p>0.50 ; \mathrm{G} 1=\mathrm{G} 2$

a2-globulin: $p>0.10 ; \mathrm{G} 1=\mathrm{G} 2$

Y-globulin: $p>0.10 ; \mathrm{G} 1=\mathrm{G} 2$

Mucoprotein: $p>0.25 ; \mathrm{G} 1=\mathrm{G} 2$

a1-glycoprotein acid: $p>0.50 ; \mathrm{G} 1=\mathrm{G} 2$

ESR: $p<0.10 ; \mathrm{G} 1>\mathrm{G} 2$ 


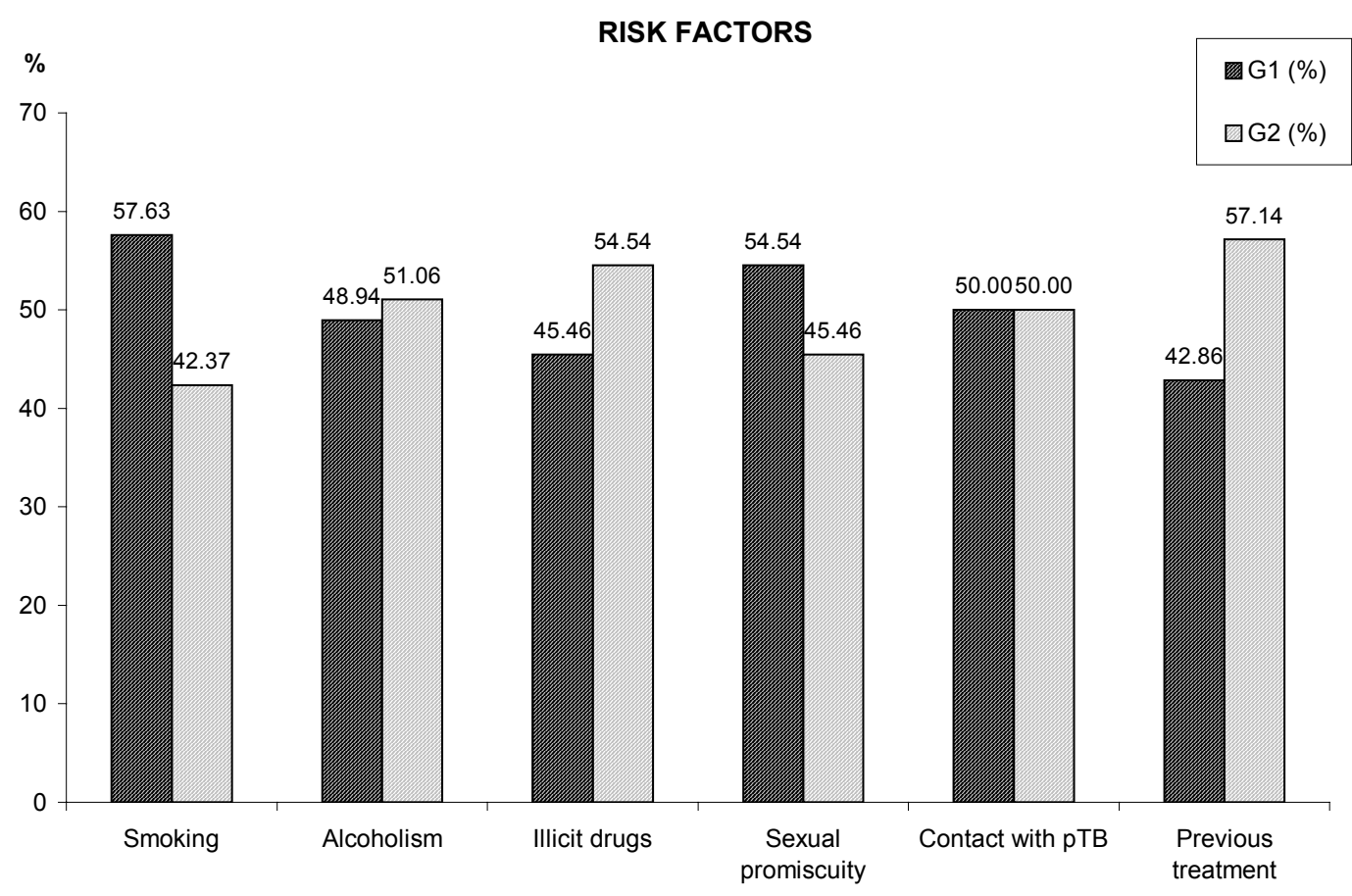

Figure 1. Risk factors associated with pulmonary tuberculosis (pTB).

Statistics: Smoking: $0.05<p<0.10$ (Comment: G1 $\geq G 2$ ); Alcoholism: $p>0.50$ (Comment $\mathrm{G} 1=\mathrm{G} 2$ ); Illicit drugs: $p>0.50$ (Comment: $\mathrm{G} 1=\mathrm{G} 2$ ); Sexual promiscuity: $p>0.50$ (Comment: $\mathrm{G} 1=\mathrm{G} 2$ ); Contact with $\mathrm{pTB}: p>0.50$ (Comment: $\mathrm{G} 1=\mathrm{G} 2$ ) and Previous treatment: $p>0.25$ (Comment: $\mathrm{G} 1=\mathrm{G} 2$ ).

G1: complaint duration up to 3 months.

G2: complaint duration over 3 months.

\section{DISCUSSION}

Tuberculosis is a highly important global chronic disease and is responsible for more deaths than other tropical diseases. Brazil has high annual incidence and mortality rates $(1,9,16,26)$.

The higher frequency of male individuals in both groups was in line with other studies $(13,21,27)$. Causes of this predominance in men in relation to women have been cited as biological differences such as immunity, exposure to $M$. tuberculosis associated with different social miscegenation profiles and social behaviors including smoking (27).

G1 and G2 mean ages were higher than the Brazilian average; this is probably due to them being referred to a high complexity treatment unit $(13,21)$. 
Bacilloscopy behavior was not significantly different between groups. This method gave a $61.25 \%$ positivity which demonstrates its low sensitivity; this is in line with current bacteriological diagnosis of tuberculosis in Brazil $(5,13,27)$. This low sensitivity could be due to the slow growth of the bacillus, or the result of infection controlled by the individual (13).

For smoking, a tendency to higher frequency was seen in the up-to-three-months group ( $G 1 \geq G 2$ ). The predominance of smokers in $\mathrm{G} 1$ reflects their lower tolerance as smoking is implicated in structural and immunological alterations of organism defense such as rupture of the respiratory epithelium, changes in pathogen adherence, prejudiced mucociliary depuration, deficiency in macrophage phagocyte activity, and $\mathrm{CD}_{4}{ }^{+} \mathrm{T}$ lymphopenia, increasing the susceptibility to pulmonary tuberculosis (3).

Alcoholism must also be highlighted even though this study did not observe any significant difference between groups. It is considered a factor that reduces organic resistance as the alcoholic does not feed himself adequately, is inclined towards gastritis which can lead to lack of appetite which can end up compromising individual nutritional state and resistance $(10,20)$. Frequent infections of the respiratory tract and inspired pneumonia also significantly contribute to the high incidence of chronic lung disease in alcoholics (20). The importance of alcoholism in tuberculosis determinism for this population can be inferred by the fact that half of them have a previous history of alcohol abuse.

For this population, drug addiction was not a risk factor, probably because of their ages, as mean ages (45 years for $\mathrm{G} 1$ and 47 years for G2) were in general much higher than those observed for drug users.

Sexual promiscuity and contact with tuberculosis, important risk factors in the epidemiology of the disease, were not very relevant in this study and were not significant between groups.

In relation to ESR and platelet count, values were higher in those with less clinical disease duration (G1), as at the beginning of the tuberculosis process there is strong pro-inflammatory cytokine activity (IFN- $\gamma$ \& TNF- $\alpha$ ) which stimulates expression of acute-phase proteins and thrombocytosis. With disease evolution, anti-inflammatory cytokine (IL-10, TGF- $\beta$ ) expression increases, which promote cooling down of inflammatory activity $(16,30)$. Also, $\alpha 2$ and $y$-globulin values are much higher than 
normal in patients with less disease duration, although not statistically significant $(2$, $3,24)$.

Finally, this study showed some degree of relationship between smoking habit, higher ESR values and platelet counts in tuberculosis patients who presented less clinical duration. Prospective studies are necessary to confirm this relationship.

\section{ACKNOWLEDGEMENTS}

To FAPESP, for a scientific grant.

\section{REFERENCES}

1 AMIN Z. Clinical tuberculosis problems and management. Acta. Med. Indones., 2006, 38, 109-16.

2 ANDUS T., BAUER J., GEROK E. Effects of cytokines on the liver. Hepatology, 1991, 13, 364-75.

3 ARCAVI L., BENOWITZ NL. Cigarette smoking and infection. Arch. Intern. Med., 2004, 164, 2206-16.

4 BALLOU SP., LOZANSKI FB., HODDER S., RZEWNICKI DL., MION LC., SIPE JD., FORD AB., KUSHNER I. Quantitative and qualitative alterations of acute-phase proteins in healthy elderly persons. Age Ageing., 1996, 25, 224-38.

5 BASTA PC., COIMBRA JR CEA., ESCOBAR AL., SANTOS RV. Aspectos epidemiológicos da tuberculose na população indígena Suruí, Amazônia, Brasil. Rev. Soc. Bras. Med. Trop., 2004, 37, 338-42.

6 BEVILACQUA MP., POBER JS., MAJEAU GR., COTRAN RS., GIMBRONE JR MA. Interleukine 1 (IL-1) induces biosynthesis and cell surface expression of procoagulant activity in human vascular endothelial cells. J. Exp. Med., 1984, 160, 618-23.

7 BRASIL. Ministério da Saúde. Secretaria de Vigilância em Saúde. Programa Nacional de Controle de Tuberculose: avanços e desafios. Brasília, 2005.

8 BROWN D., MILES B., ZWILLING B. Growth of Mycobacterium tuberculosis in BCG-resistant and susceptible mice: establishment of latency and reactivation. Infect. Immun., 1995, 63, 2243-7.

9 CHAIMOWICZ F. Age transition of tuberculosis incidence and mortality in Brazil. Rev. Saúde Pub., 2001, 35, 81-7. 
10 COHEN S., TYRRELL DA., RUSSELL MA., JARVIS MJ., SMITH AP. Smoking, alcohol consumption, and susceptibility to the common cold. Am. J. Public Health, 1993, 83, 1277-83.

11 DANNENBERG JR A. Delayed-type hypersensitivity and cell-mediated immunity in the pathogenesis of tuberculosis. Immunol. Today, 1991, 12, 228-33.

12 DLUGOVITZKY D., TORRES-MORALES A., RATENI L., FARRONI MA., LARGACHA C., MOLTENI O., BOTTASSO O. Circulating profile of Th1 and Th2 cytokines in tuberculosis patients with different degrees of pulmonary involvement. FEMS Immunol., 1997, 18, 203-7.

13 FERREIRA AAA., QUEIROZ KCS., TORRES KP., FERREIRA MAF., ACCIOLY H., ALVES MSCF. Os fatores associados à tuberculose pulmonar e a baciloscopia: uma contribuição ao diagnóstico nos serviços de saúde pública. Rev. Bras. Pneumol., 2005, 8,142-49.

14 FLYNN J., GOLDSTEIN M., CHAN J., TRIEBOLD K., PFEFFER K., LOWENSTEIN C., SCHRELBER R., MAK TW., BLOOM BR. Tumor necrosis factor- $\alpha$ is required in the protective immune response against Mycobacterium tuberculosis in mice. Immunity, 1995, 2, 561-72.

15 KARTALOGLU Z., CERRAHOGLU K., OKUTAN O., OZTURK A., AYDILEK R. Parameters of blood coagulation in patients with pulmonary tuberculosis. J. Intern. Med., 2001, 2, 2.

16 LIMA FILHO MT. Patogenia da tuberculose. J. Pneumol., 1993, 19, 11-18.

17 OPPENHEIM JJ., GERY I. Interleukin-1 is more than an interleukin. Immunol. Today, 1982, 3, 113-19.

18 RAVIGLIONE MC., SNIDER JR DE., KOCHI A. Global epidemiology of tuberculosis: morbidity and mortality of a worldwide epidemic. J. Am. Med. Assoc., 1995, 273, 220-26.

19 RICH EA., TORRES M., SADA E., FINEGAN CK., HAMILTON BD., TOOSSI Z. Mycobacterium tuberculosis (MTB)-stimulated production of nitric oxide by human alveolar macrophages and relationship of nitric oxide production to growth inhibition of MTB. Tuber. Lung Dis., 1997, 78, 247-55.

20 RUFFINO MC., NETO AR. Associação entre alcoolismo e tuberculose pulmonar. Rev. Saúde Púb., 1979, 13, 183-94. 
21 SANTO AH., PINHEIRO CE., JORDANI MS. Causas múltiplas de morte relacionadas à tuberculose no Estado de São Paulo, 1998. Rev. Saúde Púb., 2003, 37, 714-21.

22 SANTOS VM., CUNHA SF., CUNHA DF. Velocidade de sedimentação das hemácias: utilidades e limitações. Rev. Assoc. Med. Brasil, 2000, 46, 232-6.

23 SHIRAN SD., BOVIN NV. Carbohydrate composition and immunomodulatory activity of different glycoforms of alpha-1-acid glycoprotein. Glycoconj. J., 1997, 14, 631-38.

24 SINGH KJ., AHLUWALIA G., SHARMA SK., SAXENA R., CHAUDHARY VP., ANANT M. Significance of haematological manifestation in patients with tuberculosis. J. Assoc. Physicians India, 2001, 49, 790-94.

25 SOX HC., LIANG MH. The erythrocyte sedimentation rate. Ann. Int. Med., 1986, 104, 515-23.

26 SUDRE P., TEN DAM G., KOCHI A. Tuberculosis: a global overview of the situation today. Bull. W. H. O., 1992, 70, 149-59.

27 WATKINS RE., PLANT AJ. Does smoking explain sex differences in the global tuberculosis epidemic? Epidemiol. Infect., 2006, 134, 333-39.

28 WINZLER RJ. The plasma proteins. Nova York: Academic Press, 1960.

29 WOLFE F. Comparative usefulness of C-reactive protein and erythrocyte sedimentation rate in patients with rheumatoid arthritis. J. Rheumatol., 1997, 24, 1477-85.

30 YAMADA H., MIZUMO S., HORAI R., IWAKURA Y., SUGAWARA I. Protective role of interleukin-1 in mycobacterial infection in IL-1 $\alpha / \beta$ double-knockout mice. Lab. Invest., 2000, 80, 759-67. 